\title{
Effects of copper and cadmium spiked-sediments on embryonic development of Japanese medaka (Oryzias latipes)
}

Iris Barjhoux ${ }^{\mathrm{a}}$, Magalie Baudrimont ${ }^{\mathrm{b}}$, Bénédicte Morina ${ }^{\mathrm{a}}$, Laure Landi ${ }^{\mathrm{a}}$, Patrice Gonzalez ${ }^{\mathrm{b}}$, Jérôme Cachot ${ }^{\mathrm{a}}$

1 a Univ. Bordeaux, EPOC/LPTC, UMR 5805, F-33400 Talence, France

2 b Univ. Bordeaux, EPOC/EA, UMR 5805, F-33400 Talence, France

Contact author: Jérôme Cachot

Postal address: UMR 5805 EPOC, CNRS, LPTC group, University of Bordeaux, 351 cours de la Libération, 33405 Talence Cedex, France

Email address: jerome.cachot@u-bordeaux1.fr

Phone: +33 (0)5 40003830

Fax: $+33(0) 540002267$ 


\begin{abstract}
3 Because of their high capacity to accumulate contaminants such as persistent organic pollutants and heavy 4 metals, aquatic sediments are considered as a long-term source of contamination for aquatic organisms. In 5 compliance with the increasing interest both for sediment quality evaluation and the use of fish early life stage 6 (ELS) toxicity assays, we proposed an embryo-larval test to evaluate embryotoxicity and genotoxicity of 7 sediment-bound contaminants. Pre-blastula stage medaka (Oryzias latipes) embryos were exposed by static 8 sediment contact to two model heavy metals (cadmium and copper) at environmental concentrations during the 9 whole 10-day embryonic development. Lethal and sub-lethal effects were recorded in both embryos and larvae 10 for 20dpf (days post fertilisation) using several global toxicity and phenotypic endpoints. The comet assay was 11 also performed on medaka prolarvae to evaluate genotoxic effects of the tested chemicals. Environmental 12 concentrations of cadmium $(\mathrm{Cd})$ and copper $(\mathrm{Cu})$ did not affect embryo and larval survival. However, both 13 heavy metals significantly induced morphological abnormalities, particularly spinal and cardiovascular 14 deformities. Cd but not $\mathrm{Cu}$ induced tachycardia. Both heavy metals induced a significant increase in DNA 15 damage at all tested concentrations. Resulting LOEC values for $\mathrm{Cd}$ and $\mathrm{Cu}$ corresponded to 1.9 and $8.5 \mu \mathrm{g} / \mathrm{g} \mathrm{dw}$ 16 sediment respectively. Although metal bioavailability is probably lower for naturally-contaminated sediments, 17 the relatively low toxicity thresholds for both $\mathrm{Cd}$ and $\mathrm{Cu}$ raise the question of possible risk for fish embryos 18 developing in direct contact to sediments. This study demonstrates the applicability, sensitivity and relevance of 19 the Japanese medaka embryo-larval assay (MELA) to evaluate sediment hazardous potency at environmental 20 concentrations of heavy metals.
\end{abstract}

21 Keywords: Medaka embryo-larval assay, sediment, teratogenicity, genotoxicity, heavy metals 


\section{Introduction}

24 The European Water Framework Directive (WFD) aims to reach a good ecological and chemical status in all European surface waters by 2015 (EC, 2000). However, chemical characterisation and toxicity evaluation of sediments are not clearly required by the WFD. Actually, sediments are well-known to be important secondary sources of contamination for aquatic environment because of their high capacity to sequester and then to release a great number of persistent chemicals such as POPs (persistent organic pollutants) and heavy metals (Burton, 1991). For benthic organisms, exposure can occur via both aqueous phase (water column and porewater) and direct contact to or ingestion of contaminated particles (Kosmehl et al., 2006). For these reasons, sediments play a non-negligible role in the pollutants' bioavailability and route of exposure especially for benthic organisms. Consequently, they represent key compartments that have to be taken into account in risk assessment approaches recommended by the WFD.

Several test phases have been used for sediment toxicity testing (Burton, 1991) as for instance extractable phase, pore water and in situ assays (sediment test chamber, in situ mesocosm...). However, whole sediment exposure is generally considered as the most realistic integrative method to mimic in situ contamination of organisms because the uptake route (including sediment-contact and aqueous phase exposure) is very similar to that in environmental conditions, taking sediment characteristics and chemical properties into account (Hollert et al., 2003; Kosmehl et al., 2006; Mages et al., 2008).

In recent years, fish embryos have gained interest in risk assessment procedures because of their high sensitivity to pollutants and their ecological relevance (e.g. recruitment, population wellness, Burton, 1991; Cao et al., 2009) and also because of the new European regulation on the protection of animals used for scientific purpose (EC, 2010). Considering that sediments are putative spawning substrates for many pelagic and benthic organisms including fish, the use of fish early life stage (ELS) to evaluate sediment contamination would enable effects on hatchability, development and growth, which are considered as critical endpoints, to be monitored (Burton, 1991).

In this context, an increasing number of studies proposed whole sediment-contact bioassays using fish embryos, (Hollert et al., 2003; Hallare et al., 2005a; Kosmehl et al., 2006). In these studies, the potentially lethal and teratogenic effects of the tested sediments were assessed using classical endpoints such as embryonic survival, hatching rate, growth retardation, heart rate and developmental abnormalities. An adaptation of the comet assay was also proposed to evaluate the genotoxicity of whole sediments (Kosmehl et al., 2006; Kosmehl et al., 2008). All these works clearly demonstrate the suitability of such embryo-larval assays for natural sediment testing as it enables complex environmental matrices containing several chemicals in mixture to be analysed and the sole bioavailable fraction of particle-bound pollutants to be evaluated. However, to our knowledge, very few studies used this approach to measure the toxicity of single compounds artificially coated onto sediments and only hydrophobic organic pollutants were concerned (Vicquelin et al., 2011).

57 Japanese medaka embryos offer the same advantages than zebrafish embryos for developmental toxicity testing i.e.: transparent chorion, lack of pigments in embryos which facilitates non-invasive observations during the development; sensitivity to toxicant exposure (e.g.: Gonzalez-Doncel et al., 2003a; Farwell et al., 2006;

60 Gonzalez-Doncel et al., 2008); well-described stages of development (Iwamatsu, 2004; Gonzalez-Doncel et al., 
2005); small size; adaptability to various environmental conditions (Carlson et al., 2002; Wittbrodt et al., 2002; Yao et al., 2010); low maintenance cost; short maturation time (Wittbrodt et al., 2002) and spawning all over the year in good breeding conditions (Iwamatsu, 2004). However, whereas zebrafish embryos hatch after 2-3 days of development, medaka embryos development extends up to 9 days at $26^{\circ} \mathrm{C}$. This longer embryo development in the egg provides the possibility to extend the duration of embryonic exposure up to 9-10 days instead of 48 hours, which can mimic a more chronic exposure to contaminants. Furthermore, Japanese medaka is tolerant to a wide range of temperatures and salinities allowing experiments in very contrasted thermal and salinity conditions. Finally, one of the major advantages of the Japanese medaka is the low baseline embryo and larval mortality.

Heavy metals are among the most widespread pollutants in environment and have a high potency to accumulate in sediments (Burton, 1991; Chapman et al., 1998). It has been well documented that excessive aqueous cadmium $(\mathrm{Cd})$ or copper $(\mathrm{Cu})$ exposure could lead to dramatic effects on fish embryos such as high mortality, low hatchability, delay in time to hatch, reduced length, weight and head height, cardiac activity disturbances and numerous developmental impairments including craniofacial alterations, yolk sac abnormalities, spinal deformities, oedemata, cardiovascular disturbances and lack of pigmentation (reviewed by Jezierska et al., 2009). In addition, both heavy metals have been reported as potent genotoxicants in several fish cell lines, generating reactive oxygen species (ROS) that can induce DNA strand breaks and trigger apoptosis and/or cell death (Risso-de Faverney et al., 2001; Manzl et al., 2004; Sandrini et al., 2009).

However, to our knowledge, there is a lack of data on the bioavailability and effects of sediments specifically contaminated by heavy metals on fish embryos development. Furthermore, this kind of approach could be extremely useful to calculate toxicity thresholds (LOEC) of particle-bound pollutants in fish and to derive sediment quality guidelines (PNEC).

The objective of the present work is to characterise both the teratogenic and genotoxic effects of $\mathrm{Cd}$ and $\mathrm{Cu}$ using a modified version of the Japanese medaka embryo-larval assay (MELA) (Helmstetter and Alden, 1995) and spiked sediments as source of contaminants. Medaka embryos were exposed to spiked sediments during their whole embryonic development. In the course of the exposure several lethal and sublethal endpoints were followed at both embryonic and larval stages, including cardiac activity, hatching, developmental impairments and survival. In addition, a comet assay was performed on 2-day old larvae to evaluate DNA damage induced by heavy metals.

\section{Materials and Methods}

\subsection{Chemicals}

$94 \mathrm{CdCl}_{2}: 2 \mathrm{H}_{2} \mathrm{O}$, phosphate-buffered saline (PBS), nitric acid $65 \%$ and normal melting point agarose (NMP) were 95 purchased from Fluka Chemie (Buchs, $\mathrm{CH})$. Cu standard $1000 \mathrm{mg}$ Titrisol ${ }^{\circledR}\left(\mathrm{CuCl}_{2}\right.$ in $\left.\mathrm{H} 2 \mathrm{O}\right)$ was purchased from

96 Merck (Darmstadt, DE). Tricaine methanesulfonate (MS222), low melting point agarose (LMP) and collagenase 


\subsection{Reference sediment characterisation}

The reference sediment was collected in the Lot river, on Marcenac site (December 2008, SW France), which is considered as a pristine site for heavy metal contamination in the Lot/Garonne/Gironde continuum (Audry et al., 2004; Audry et al., 2010). The reference sediment was stored at $-20^{\circ} \mathrm{C}$, then freeze-dried and finally slightly crushed using a mortar and a pestle to eliminate larger particles and homogenise particle size before use.

The particle-size distribution and particulate organic carbon concentration of the freeze-dried crushed sediment were determined by diffractometry and infrared spectroscopy (Etcheber et al., 1999) respectively. Dissolved ammonium and sulphide were measured in pore waters extracted from the sediment using colorimetric procedures (Strickland and Parsons, 1972) and spectrophotometrical analyses with the methylene blue method (Cline, 1969) respectively. Detailed protocols used for the forementioned analyses are described by Vicquelin et al. (2011).

\subsection{Sediment spiking}

113 Four spiking concentrations were determined using $\mathrm{Cd}$ contents recorded in sediments along the Lot-GaronneGironde continuum (Table 1). A 0.3X-concentration ( $2 \mu \mathrm{g} / \mathrm{g} \mathrm{dw}$ sediment) mimicked a low Cd-impacted area (e.g. La Reole on Garonne river), a 1X-concentration $(6.5 \mu \mathrm{g} / \mathrm{g} \mathrm{dw})$ was selected as a mean Cd-level present in the fluvial-estuarine system and a 3X-concentration $(20 \mu \mathrm{g} / \mathrm{g} \mathrm{dw})$ was not set to represent the highest concentration but a moderate $\mathrm{Cd}$ content as measured along the Lot river (e.g. Carjac site). A control treatment $(0 \mu \mathrm{g} / \mathrm{g} \mathrm{dw})$ was also added to the conditions cited above. The same concentrations were tested for the $\mathrm{Cu}$ treatment to allow comparison of effects between the two metals.

120 The $30 \mathrm{X} \mathrm{Cd}$-stock solution $(2.5 \mathrm{mgCd} / \mathrm{mL})$ was obtained by adding $48.79 \mathrm{mg}$ of $\mathrm{CdCl}_{2}: 2 \mathrm{H}_{2} \mathrm{O}$ to $10 \mathrm{~mL}$ of 121 ultrapure water (Milli-Q Maxima, Elga Labwater, Veolia water, Blagnac FR). The $\mathrm{Cu}$-stock solution was made by diluting $\mathrm{Cu}$ standard $1000 \mathrm{mg}\left(\mathrm{CuCl}_{2}\right)$ in $1 \mathrm{~L}$ of ultrapure water. Dilutions of these $\mathrm{Cd}$ and $\mathrm{Cu}$ stock solutions were performed in ultrapure water to obtain the three contamination solutions used for sediment spiking.

124 For each treatment, $25 \mathrm{~g} \mathrm{dw}$ of sediment was spiked by adding $2 \mathrm{~mL}$ of contamination solution (or ultrapure water for control treatment) and $11 \mathrm{~mL}$ of ultrapure water as homogenising solvent. The whole mixture was kept under agitation for $1 \mathrm{~h}$ then, once supernatant removed at most, kept all night at room temperature for partial drying. The spiked-sediment moisture content was gravimetrically determined to calculate the wet weight (ww) equivalent to $5 \mathrm{~g} \mathrm{dw}$ for each condition. After manual homogenisation, the sediment of a same spikingconcentration was divided into five aliquots of $5 \mathrm{~g} d \mathrm{w}$ equivalent. Three aliquots were kept for embryo-toxicity testing, another one was used for chemical analysis (T0 measurement) and the last one was saved as a supplement. 
134 Mature Japanese medakas were reared and maintained in 40L-tanks with a male:female ratio of 1:2, at a 135 temperature of $26^{\circ} \mathrm{C}$ with a photoperiod of $12 \mathrm{~h}$ light: $12 \mathrm{~h}$ dark. Tanks were cleaned using a siphon and $30 \%$ was 136 renewed with stalling water (1/3 24h-dechlorinated tap water and 2/3 purified water by reverse osmosis; $\mathrm{pH} 7.5$;

13753.4 ppm $\mathrm{CaCO}_{3} ; 0.025$ ppm NO $\mathrm{NO}_{2} ; 1.5 \mathrm{ppm} \mathrm{PO}_{4} ; 5$ ppm NO $\mathrm{N}_{3} ;<0.1 \mathrm{ppm} \mathrm{NH}$ ) twice a week. Fishes were fed once 138 a day with dry flakes (Tetramin ${ }^{\circledR}$ Tropical, Tetra, Melle, Germany) and once a day with brine shrimp nauplii 139 Artemia sp. nauplii (Ocean Nutrition, Assen, Belgium). It was visually checked daily and unhealthy fish 140 individuals were removed and euthanized using MS222 solution at $1 \mathrm{~g} / \mathrm{L}$. During the spawning stimulation 141 period, medaka genitors were reared at $28^{\circ} \mathrm{C}$ under a $16 \mathrm{~h}: 8 \mathrm{~h}$ light:dark photoperiod and fed four times a day.

142 Females were examined for eggs $1 \mathrm{~h}$ after onset of light and egg clusters were gently removed by hand and 143 placed in Egg Rearing Solution (ERS; $17.11 \mathrm{mM} \mathrm{NaCl} ; 0.4 \mathrm{mM} \mathrm{KCl} ; 0.36 \mathrm{mM} \mathrm{CaCl}_{2} ; 1.36 \mathrm{mM} \mathrm{MgSO}_{4} ; \mathrm{pH}_{7.0}$ ). 144 Harvested eggs were pooled and then individualised by rolling them softly to sever attaching filaments. Finally, 145 they were staged according to Iwamatsu (2004) and Gonzalez-Doncel et al. (2005) under a stereomicroscope 146 (Leica MZ75, Leica Microsystems, Nanterre, France) and cold light source (Intralux® 4100, Volpi AG,

147 Schlieren, Switzerland) to discard unfertilised or dead individuals and only pre-morula stage embryos (2-4hours 148 post fertilisation, hpf) were selected for the study. Animal breeding and experiments on embryos and larvae were 149 conducted in accordance to the EU directive 210/63/EU on the protection of animals used for scientific purposes.

\subsection{Embryos exposure by sediment-contact}

152 Two distinct experiments were performed for $\mathrm{Cd}$ and $\mathrm{Cu}$ toxicity analysis. Both experiments followed the same 153 general protocol, which consisted of three independent replicates for each condition. As mentioned above, $5 \mathrm{~g}$ $154 \mathrm{dw}$ sediment were placed in a $35 \mathrm{~mm}$ diameter plastic Petri dish for each replicate and each concentration.

155 Sediment was then covered with $1 \mathrm{ml}$ of ERS buffer at $\mathrm{pH} 7$ and then maintained at $26^{\circ} \mathrm{C}$ for 4 to 5 hours before 156 the beginning of the experiment.

157 Immediately after sorting, 30 embryos per replicate were randomly placed on a Nitex ${ }^{\circledR}$ mesh (mesh opening $1581000 \mu \mathrm{m}$, Sefar Filtration Inc., Depew, NY, US) which was then slightly sunk into the sediment to allow a good 159 contact between the embryos and the sediment without any risk that embryos might get entirely buried into the 160 sediment and die from hypoxia. ERS levels in exposure dishes were daily checked and topped in case of 161 evaporation. Dissolved oxygen was measured daily throughout the 10-day exposure period in the reference 162 sediment (Marcenac freeze-dried sediment) using a Clark-type sensor equipped with a guard cathode (Unisense, 163 Aarhus, DK) and connected to a high sensitivity picoammeter (PA2000, Unisense). Good oxygenation of the 164 medium was confirmed with values always superior to $80 \%$ saturation in the water column and at the water165 sediment interface (Data not shown).

166 Embryos were maintained in contact to the sediment during their whole embryonic development until 'hatching 167 peak' usually around day 9-10 post-fertilisation (dpf) in control condition. Afterwards, unhatched embryos were 168 transferred to new Petri dishes with $3 \mathrm{~mL}$ of clean ERS and sediments were collected for T10 heavy metal 169 analysis. Once hatched, larvae were placed in beakers containing $50 \mathrm{~mL}$ of clean stalling water which was 170 renewed $(100 \%)$ every 2 days. 48hours post-hatching (hph) larvae were fed twice a day with TetraMin ${ }^{\circledR}$ Baby 171 (Tetra, Melle, DE) flake food until 20dpf. 
172 During the whole experiment, embryos and larvae were maintained in a climate cabinet (Economic Delux,

173 Snijders Scientific, Tilburg, NL) at $26^{\circ} \mathrm{C} \pm 0.3$ with a $12 \mathrm{~h}: 12 \mathrm{~h}$ photoperiod and 5000Lux white light.

\subsection{Lethal and sub-lethal endpoints}

Viability was checked daily at embryonic and larval stages, during the whole experiment (day 1 to 20pf). Dead embryos (whitish opaque appearance or absence of cardiac contraction after $3 \mathrm{dpf}$ ) were counted and removed from each replicate.

179 Cardiac activity was assessed at day 6 and $7 \mathrm{pf}$. Five randomly selected embryos per replicate were taken into account for this parameter. Heartbeats were counted in three 20s-intervals per individual using Leica MZ75 stereomicroscope (Leica Microsystems, Nanterre, France) and a cold light source (Intralux® 4100, Volpi AG,

182 Schlieren, Switzerland). Room temperature was maintained at $23 \pm 1^{\circ} \mathrm{C}$. These three measurements were then added to obtain cardiac activity in beats per minute. The five individual measurements were finally averaged to determine the mean cardiac activity for a replicate.

Time to hatch and hatching success were checked daily from the day of first hatching to the end of the experiment at day 20pf. Only embryos able to fully exit chorions were considered as 'hatched', others were counted as 'not hatched'. Successfully hatched larvae were taken into account for time to hatch determination, noting the date of hatching and considering that the day of fertilisation was day 0.

189 Biometric measurements at hatching were performed every day on all newly hatched larva. Larvae were 190 observed under a stereomicroscope (MZ75) equipped with a colour CDD camera (Leica DFC 420C), connected 191 to a computer. A picture of whole body larvae was taken, and total body length (from the end of lower jaw to the

192 end of caudal fin) as well as head size (from the end of lower jaw to pectoral fin attachment level) were assessed 193 thanks to an image analysis software program (Leica Application Suite v2.8.1). The ratio between head size and 194 total body length (called further 'head/length ratio', expressed in percentage) was also calculated to follow 195 possible changes in larva proportions.

196 Development abnormalities were observed every day on each newly hatched larva. Six different categories of abnormalities were recorded including: pericardial, perivitelline and cranial oedemata; spinal deformities (scoliosis, lordosis, kyphosis, C-shaped larvae and tail malformations); craniofacial deformities (skull and jaw deformities including underdevelopment); eye anomalies (hyper- hypo- or dystrophia, pigmentation alteration, hypopigmentation, absence of eye); cardio-vascular anomalies (hyper- hypo- or dystrophia, positioning abnormality, incomplete or abnormal heart looping, tubular heart characterised by an absence of chamber differentiation, anemia resulting in an absence of blood circulating cells, haemorrhage, local accumulation of motionless blood cell) and yolk-sac anomalies (mainly yolk malabsorption).

\subsection{Comet assay}

The comet assay was performed at day 12pf on a pool of 5 larvae per replicate. Pools of larvae were digested in a MEM-Collagenase IV $0.125 \%$ (w/v) medium, and after cell viability (superior to $80 \%$ ) evaluation using a trypan blue exclusion test, the comet assay was carried out following Morin et al. (2011) protocol. Ethidium bromide $(20 \mu \mathrm{g} / \mathrm{L})$ was used as DNA fluorescent tag and all coded-slides were randomly analysed for 75 nuclei per gel 
(two gels per experimental replicate) using an Olympus epi-fluorescent microscope (400x magnification)

211 equipped with a grayscale CCD camera (Zeiss, DE) and Komet 5.5 software program (Kinetic Imaging,

212 Liverpool, UK). As recommended by Hartmann et al. (2003), \%tail DNA (percentage of DNA which migrates

213 from the nucleus i.e. the head of the comet) was the selected parameter to be used for DNA damage

214 measurement. Heavily DNA damaged nuclei displaying small or inexistent head and large diffuse tail and known

215 as hedgehogs, were not taken into account in the comet measurement as recommended by Kumaravel et al.

216 (2009). However, the percentage of hedgehogs which have been reported as apoptotic or necrotic cells (Olive

217 and Banath, 1995) was visually scored on a total of 100 cells per gel.

\section{$219 \quad 2.8$ Heavy metals analysis}

220 For each sample, ERS buffer was separated from sediment by a 15 min centrifugation at $4000 \mathrm{rpm}$ at room 221 temperature.

222 About $1 \mathrm{~g} \mathrm{ww}$ of each sediment sample was dried for $48 \mathrm{~h}$ at $60^{\circ} \mathrm{C}$ and then digested with $3 \mathrm{ml} 65 \%$ nitric acid

223 for $3 \mathrm{~h}$ at $100^{\circ} \mathrm{C}$. Each batch of samples included method blanks and certified reference materials (Tort-2, lobster

224 hepatopancreas, NRCC-CNRC, Ottawa, CA) and measured values were consistently within certified ranges (data 225 not shown). After mineralisation, samples were diluted by addition of $15 \mathrm{ml}$ ultrapure water (MilliQ, Bedford,

226 MA, USA) and metal determinations were performed using an atomic absorption spectrophotometer (Varian 227 SpectrAA 220 FS, Agilent Technologies, Santa Clara, US).

228 For ERS buffer analysis, about $3 \mathrm{~mL}$ of each sample was acidified with $1 \%$ final v/v 65\% nitric acid. Samples 229 were then analysed for $\mathrm{Cd}$ and $\mathrm{Cu}$ contents by ICP-AES (Varian Vista ProAxial, Agilent Technologies, Santa 230 Clara, US) user standard conditions. Method blanks were added to each set of samples. The quality of the 231 analytical method was checked by analysing the certified international reference water.

\subsection{Statistical analysis}

234 The data is expressed as mean \pm standard deviation (SD). Statistical analyses were conducted using Statistica 7.1 235 software program (Statsoft, Maisons-Alfort, FR). Results were initially tested for normality (Shapiro-Wilk test 236 on residues with $1 \%$ risk) and equality of variance (Levene test, 5\% risk). If necessary, data were $\log$ 237 transformed to fulfil normality and equality of variance criteria. Afterwards, significant differences between 238 treatments were tested with one way ANOVA - Variance analysis followed by post-hoc Tukey test $(\mathrm{p}<0.05)$. If 239 data transformation was not sufficient to perform parametric analysis, non-parametric Kruskall-Wallis ANOVA and its post-hoc test (analogous to Bonferroni-Dunn's test) were used $(\mathrm{p}<0.05)$.

\section{3. Results}

\subsection{Reference sediment characterisation}


Particle sizes of Marcenac sediment ranged from very fine sand to silt with a median value of $111.5 \mu \mathrm{m}$. The particulate organic carbon content was low $(0.11 \%)$ and dissolved ammonium and sulphide in pore water reached $62 \mu \mathrm{M}$ and $17 \mu \mathrm{M}$ respectively (Table 2).

\subsection{Heavy metal content in water and sediments}

Table 3 shows $\mathrm{Cd}$ and $\mathrm{Cu}$ concentrations determined in the sediments at the beginning (T0) and at the end (T10) of the embryos' exposure. Heavy metal natural background (mean of control measurement) in sediment was evaluated at $0.17 \pm 0.04 \mu \mathrm{g} / \mathrm{g} \mathrm{dw}$ for $\mathrm{Cd}$ and $7.18 \pm 0.49 \mu \mathrm{g} / \mathrm{g} \mathrm{dw}$ for $\mathrm{Cu}$. In addition, several other trace metals were present in the reference sediment (Table 3) including $\mathrm{Co}, \mathrm{Mn}, \mathrm{Ni}, \mathrm{Zn}, \mathrm{Cr}, \mathrm{As}, \mathrm{Ag}$ and $\mathrm{Pb}$. In contrast, PAHs, PCBs and organochlorinated pesticides were detected at extremely low concentrations (Data not shown).

A clear dose-dependent increase of $\mathrm{Cu}$ and $\mathrm{Cd}$ contents was observed for $\mathrm{Cu}$ - and $\mathrm{Cd}$-spiked sediments respectively. Measured $\mathrm{Cd}$ concentrations were very close to nominal values while $\mathrm{Cu}$ concentrations were slightly above, likely because of the natural background level of $\mathrm{Cu}$ in Marcenac sediment. The comparison between $\mathrm{T} 0$ and $\mathrm{T} 10$ values showed that more than $80 \%$ of the initial $\mathrm{Cu}$ or $\mathrm{Cd}$ concentrations were still present in the sediments at the end of the exposure (Table 3). These results indicate that sediment contamination remained stable over time and that treatments are significantly different from one another.

$\mathrm{Cd}$ and $\mathrm{Cu}$ concentrations were also measured in the overlapping ERS buffer from the reference and spiked sediments (Table 4). The Cd content of the ERS buffer was below the quantification limit in both ERS and sediment controls but increased in a dose-dependent manner from 8 to $266 \mu \mathrm{g} / \mathrm{L}$ for the three Cd-spiked sediments. $\mathrm{Cu}$ content was below the quantification limit for the control ERS but it reached $14.2 \mu \mathrm{g} / \mathrm{L}$ for the control sediment. This unexpected contamination was likely issued from the desorption of particle-bound $\mathrm{Cu}$ in the control sediment. A slight increase of $\mathrm{Cu}$ content from 29 to $60 \mu \mathrm{g} / \mathrm{L}$ was noticeable for the three $\mathrm{Cu}$-spiked sediments. Data comparison between $\mathrm{T} 1$ and $\mathrm{T} 9$ showed that $\mathrm{Cd}$ concentrations remained globally constant while $\mathrm{Cu}$ concentrations decreased with time from 30 to $45 \%$. The pH of the ERS buffer only slightly varied from 7.0 to 7.7 in the course of the experiment.

\subsection{Embryonic and larval survivals}

$272 \mathrm{Cd}$ and $\mathrm{Cu}$ tested concentrations did not induce lethal effects on both embryos and larvae. Viability for Cdexposed fish ranged from 81 to $91 \%$ at the embryonic stage (Fig. 1a) and from 80 to $85 \%$ at the larval stage (Fig. 1b) according to exposure conditions. Similarly, Cu-exposed embryos' viability ranged from 93 to $99 \%$ (Fig. 1a) and larval survival ranged from 71 to $81 \%$ (Fig. 1b) for the various treatments.

\subsection{Hatching rate and time to hatch}

Almost all viable embryos hatched before the end of the experiment for both heavy metal exposures. As a result, hatching rates were very close to embryonic viability and no significant difference was observed in the treatments. Indeed, mean hatching success ranged from 80 to $91 \%$ for Cd-exposed embryos and from 93 to 99 $\%$ for Cu-exposed embryos (Fig. 2a). 

either. Actually, for both experiments, mean time to hatch was around 10.2 $\pm 0.17 \mathrm{dpf}$ (Fig. 2b) for all treatment groups.

\subsection{Cardiac activity}

$\mathrm{Cu}$ exposure did not affect the embryos' cardiac activity in comparison to that of the control group, neither at $6 \mathrm{dpf}$ nor at $7 \mathrm{dpf}$. Conversely, heartbeats of $6 \mathrm{dpf}$-embryos were significantly increased at $\mathrm{Cd}-3 \mathrm{X}$ concentration compared to those of the control group (156 and 131 beats/min on average respectively, Fig. 3a). This result was confirmed at $7 \mathrm{dpf}$, with a significant increase of cardiac activity in embryos exposed to $\mathrm{Cd}-1 \mathrm{X}$ and $\mathrm{Cd}-3 \mathrm{X}$ in comparison to the control group (156, 160 and 137 beats/min on average respectively, Fig. 3b).

\subsection{Biometric measurements}

Neither $\mathrm{Cd}$ nor $\mathrm{Cu}$ exposure induced modifications of larval biometric parameters, as compared to the respective control groups. Total body length of Cd-exposed larvae ranged from 4.95 to $5.00 \mathrm{~mm}$ on average (Fig. 4a), head size from 1.05 to $1.07 \mathrm{~mm}$ on average (Fig. 4b) and head/length ratio from 21.5 to $22.1 \%$ on average (Fig. $4 \mathrm{c}$ ). Interestingly, a slight significant increase of the three biometric parameters was observed on larvae from the $\mathrm{Cu}$ $3 \mathrm{X}$ group in comparison to $\mathrm{Cu}-0.3 \mathrm{X}$ group (average total length, $5.03 \mathrm{~mm}$ and $4.90 \mathrm{~mm}$ respectively; average head size, $1.11 \mathrm{~mm}$ and $1.05 \mathrm{~mm}$ respectively; average head/length ratio, $22.0 \%$ and $21.5 \%$ respectively; Fig. $4 a b c)$.

Average values for these measurements were very similar in control groups of $\mathrm{Cd}$ and $\mathrm{Cu}$ exposures.

\subsection{Morphological abnormalities}

304 Morphological abnormalities on medaka larvae were recorded on hatching day for each individual and summarised in table 5. Percentages of abnormal larvae in control groups were around $20 \%$. Larval abnormalities in Cd-exposed groups were superior to $60 \%$ and significantly different $(p=0.01)$ from those of the control treatment. More precisely, $\mathrm{Cd}$ exposure significantly increased the percentage of larvae developing spinal deformities (mainly kyphosis, lordosis and C-shaped larvae) and cardio-vascular anomalies (mainly abnormal positioning and heart looping) at $0.3 \mathrm{X}$ and $3 \mathrm{X}$ concentrations (for $1 \mathrm{X}$ group, $p=0.074$ ).

$310 \mathrm{Cu}$ exposure had overall the same effect as $\mathrm{Cd}$. The percentage of deformed larvae significantly increased 311 ( $p=0.04)$ up to $50 \%$ for each contaminated groups in comparison to control treatment $(17 \%$ of deformed 312 larvae). As observed during the $\mathrm{Cd}$ experiment, developmental abnormalities mainly concerned spinal column 313 (kyphosis and lordosis) and cardiovascular system (abnormal positioning and heart looping). Percentage of 314 individuals affected by this kind of deformities was significantly higher in $\mathrm{Cu}-3 \mathrm{X}(p=0.049)$ and $\mathrm{Cu}-1 \mathrm{X}$ 315 ( $p=0.020)$ groups respectively in comparison to control treatment. Average percentage of individuals with spinal 316 deformities in $\mathrm{Cu}-0.3 \mathrm{X}$ treatment was close to significance threshold with $p=0.077$. Moreover, yolk 317 malabsorptions were significantly increased by $\mathrm{Cu}-1 \mathrm{X}$ treatment compared to control (23\% and $9 \%$ 318 respectively). $p$ value between $3 \mathrm{X}$ - and control groups was not far from significance threshold $(p=0.061)$. 


\subsection{Genotoxic effects}

321 The mean percentage of tail DNA measured in control groups was inferior to $10 \%$ which confirmed that cells,

322 even after dissociation treatment, were in satisfactory conditions for comet assay analysis (Collins, 2004).

323 Cd exposure led to a significant DNA damage induction $(p<0.001)$ from the lowest concentration as shown by 324 the significant increase in the percentage of tail DNA from $7 \%$ for the control group up to $48 \%-60 \%$ in 325 average for contaminated groups (Fig. 5a). The percentage of 'hedgehog cells' showed the same response pattern 326 as it raised to $25-28 \%$ for Cd-exposed group against only $12 \%$ in the control group (Fig. 5b).

327 Interestingly, only $\mathrm{Cu}-0.3 \mathrm{X}$ and $\mathrm{Cu}-3 \mathrm{X}$ concentrations induced significant DNA damage increase in comparison 328 to control group (5\% of tail DNA in control versus $16 \%$ in Cu exposed groups in average, Fig. 5a). As noticed 329 in the Cd experiment, similar results were observed with the percentage of 'hedgehog cells', which was 330 significantly increased at the lowest, and at the highest $\mathrm{Cu}$ doses $(30 \%$ and $25 \%$ respectively, Fig. 5b) 331 compared to control (11\% in average).

\section{Discussion}

334 Medaka embryos that were allowed to develop in direct contact to control sediment in our test conditions showed 335 survival rates around $90 \%$ and $80 \%$ at embryonic and larval stages respectively and hatching success superior 336 to $85 \%$. These results are in compliance with the guidelines for ELS assays which set minimum hatching success 337 and survival rate after hatching at $80 \%$ each (OECD, 1992; OECD, 1998).

338 Average times to hatch observed in control treatment were very similar in both experiments (10.2 and $10.2 \mathrm{dpf}$ 339 for $\mathrm{Cd}$ and $\mathrm{Cu}$ exposures respectively) with more than $70 \%$ of embryos hatching at 10 pdf. These results are in 340 compliance with observations reported in the literature which describe hatching as usually occurring between 9 341 and $12 \mathrm{dpf}$ at $25-26^{\circ} \mathrm{C}$ for the Japanese medaka (Gonzalez-Doncel et al., 2003a; Farwell et al., 2006; Gonzalez342 Doncel et al., 2008).

343 Similarly, biometric measurements average values were very close to those of the control groups of both 344 experiments. Several authors reported total body length of Japanese medaka larvae at hatching between 3.8 - 4.7 $345 \mathrm{~mm}$ in average (Iwamatsu, 2004; Farwell et al., 2006; Oxendine et al., 2006). With an average total body length 346 nearby $5 \mathrm{~mm}$ for both experiments, unexposed larvae from our stockbreeding are a bit longer in comparison with 347 the data reported above. These biometric variations in unexposed individuals between experiments and 348 laboratories might be closely linked to breeding conditions of genitors and embryos development environment.

349 During both experiments, baseline cardiac activity in control embryos ranged between 130 and 140 beats per 350 minute. This data is quite inferior to that reported by González-Doncel et al. (2005) who measured a cardiac 351 rhythm stabilised at 180 beats per minutes in 7 dpf-embryos but very similar to the results obtained by Nassef et 352 al. (2010) in 6 dpf-control embryos.

353 Developmental abnormalities are currently used as sensitive endpoints in embryo-larval bioassays. In this study, 354 many kinds of defects were recorded from the optimal development (as described by Iwamatsu, 2004; Gonzalez- 
Doncel et al., 2005) and the baseline level of abnormal larvae ranged from 16 to $20 \%$ depending on the considered experiment. Such a percentage of larval abnormalities have already been reported in unexposed larvae for various fish species including medaka (Farwell et al., 2006; Benaduce et al., 2008) but was almost twice higher than the previously reported baseline data (Vicquelin et al., 2011). It may be partly explained by the metal content differences between the two reference sediments. Indeed, the reference sediment from Marcenac which was used in the present study contained detectable levels of certain metal species including $\mathrm{Cu}$ (Table 3) and it was shown that at least a fraction of the particle-bound $\mathrm{Cu}$ was released in the water column within $24 \mathrm{~h}$ after the beginning of the experiment (Table 4). Moreover, deformity categories (types of deformity and number of categories) recorded and recognition criteria (severity, minimum score for healthy/deformed classification) are variable between studies and strongly influence the number of individuals considered as 'deformed' or not. In this study, we selected a wide range of malformations categories and even weak abnormalities were taken into account.

Both lethal and sub-lethal endpoints observed in control groups enable this sediment-contact assay to be validated as it provides with acceptable conditions for medaka embryo development. As a result, natural $\mathrm{Cu}$ background level of $7 \mu \mathrm{g} / \mathrm{g} \mathrm{dw}$ in sediment corresponding in our test conditions to about $14 \mu \mathrm{g} / \mathrm{L}$ of Cu released in the water column seems to have limited effects on medaka embryo survival and development.

Spiked Cu- or Cd-concentrations of 2, 6.5 and $20 \mu \mathrm{g} / \mathrm{g}$ of dw sediment (up to $266 \mu \mathrm{g} / \mathrm{L} \mathrm{Cd}$ and $60 \mu \mathrm{g} / \mathrm{L} \mathrm{Cu}$ in water) neither affected medaka survival nor hatching success or time to hatch. Absence of acute effects using the same endpoints was also reported after waterborne exposure of medaka late morula staged embryos ( $\sim 5 \mathrm{hpf})$ to $\mathrm{Cd}$ at concentrations from 2.5 to $80 \mathrm{mg} / \mathrm{L}$. In a second experiment, $\mathrm{Cd}$ exposure was initiated during fertilisation and led to a significant reduction of hatching success from $20 \mathrm{mg} / \mathrm{L}$ of Cd (Gonzalez-Doncel et al., 2003b). In rainbow trout embryos, premature or delayed hatching was observed following exposure to $0.05-2.5 \mu \mathrm{g} / \mathrm{L} \mathrm{Cd}$ depending on the concentration level (Lizardo-Daudt and Kennedy, 2008).

Although no acute effect was observed in medaka embryos, a significant increase in morphological deformities was induced in newly hatched larvae at concentrations as low as $1.9 \mu \mathrm{g} / \mathrm{g} \mathrm{Cd}$ or $8.5 \mu \mathrm{g} / \mathrm{g} \mathrm{Cu}$ in sediment (1.9 $\mu \mathrm{g} / \mathrm{L} \mathrm{Cd}$ and $29 \mu \mathrm{g} / \mathrm{L} \mathrm{Cu}$ in water). More precisely, $\mathrm{Cu}$ significantly enhanced spinal deformities (kyphosis and lordosis mainly), cardiac anomalies (in particular abnormal positioning and heart looping) and yolk-sac malabsorption while $\mathrm{Cd}$ only affected the vertebral column and cardio-vascular system.

Numerous studies documented developmental effects of heavy metals and more specifically $\mathrm{Cd}$ and $\mathrm{Cu}$ in fish species. For instance, Pagrus major embryos exposed to 0.8 up to $3.2 \mathrm{mg} / \mathrm{L}$ of $\mathrm{Cd}$ led to $42-100 \%$ of morphological abnormalities (Cao et al., 2009). Lugowska and Witeska (2004) reported a high percentage of deformed larvae, sometimes superior to $60 \%$ among common carp individuals exposed to $0.2 \mathrm{mg} / \mathrm{L}$ of $\mathrm{Cu}$. Several categories of abnormalities have been reported including blastodermal lesions, yolk-sac and heart oedemata, haemorrhages, damaged blood vessels, hypopigmentation, craniofacial deformities including head and eye hypoplasia, cardiac abnormalities, deformed yolk sac and vertebral deformities including C-shaped larvae, shortened body and altered axial curvature (Cheng et al., 2000; Cheng et al., 2001; Lugowska and Witeska, 2004). 
representing more than $80 \%$ of all recorded defects (Jezierska et al., 2000). It had been reported that $\mathrm{Cd}$ exposure induces a reduction of myosin heavy chain production in the trunk which is correlated to a disorganisation of myotomes in the somites and results in altered spinal curvature (Cheng et al., 2000; Chow and Cheng, 2003).

As previously mentioned, fish cardiovascular system is also a target of heavy metal toxicity. Indeed various cardiovascular pathologies were described following exposures to heavy metals including haemorrhages, hypertension, oedemata (a result of an alteration of vascular permeability), megalocardias, circulatory collapse, tubular heart, heart rate alteration, red blood cells accumulation, atrium/ventricle morphology alteration, abnormal heart looping and aberrant vascular patterning (Cheng et al., 2001; Gonzalez-Doncel et al., 2003b; Cao et al., 2009; Li et al., 2009). Although these pathologies are frequently reported in the literature, little is known about the exact mechanisms involved in such cardiovascular dysfunctions. Several works previously showed an alteration of the cardiac functions following $\mathrm{Cu}$ or $\mathrm{Cd}$ exposure. For instance, zebrafish embryo heart rate was significantly increased by $\mathrm{Cu}$ exposure (Johnson et al., 2007) whereas Cd reduced the cardiac activity of the red sea bream (Cao et al., 2009) and zebrafish embryo (Hallare et al., 2005b). An explanation proposed by the authors for the alteration of cardiac functions is a perturbation of ionic channels such as $\mathrm{Ca}^{2+}$-ATPases following $\mathrm{Cd}$ treatment or $\mathrm{Na}^{+} / \mathrm{K}^{+}$-ATPases following $\mathrm{Cu}$ exposure (Wong and Wong, 2000; Eyckmans et al., 2010). The respective results of such ionoderegulation would be a reduced $\mathrm{Ca}^{2+}$ uptake leading to the observed bradychardia and stress response increasing heart rate (Johnson et al., 2007; Cao et al., 2009). It also had been shown that cardiac function and hemodynamic conditions strongly influence cardiac morphogenesis and vascular endothelium modelling (Glickman and Yelon, 2002; Sidi and Rosa, 2004). Moreover, cardiac morphologic alterations described by Hove et al. (2003) following artificial perturbations of blood flow are very similar to those observed in the present study (abnormal positioning and heart looping) after $\mathrm{Cu}$ and $\mathrm{Cd}$ exposures. These observations seemed to confirm the strong relationship existing between cardiac functions and cardiac morphogenesis as mentioned by Incardona et al. (2004).

418 In the present study, yolk-sac malabsorptions were significantly increased following embryonic $\mathrm{Cu}$ exposure to $23 \mu \mathrm{g} / \mathrm{g} \mathrm{dw}$ sediment (60 $\mu \mathrm{g} / \mathrm{L}$ in water). Lugowska and Witeska (2004) recorded yolk-sac resorption defects in common carp larvae after exposure to $0.2 \mathrm{mg} / \mathrm{L}$ of $\mathrm{Cu}$. Yolk sac area in zebrafish larvae exposed to 190-464 $\mu \mathrm{g} / \mathrm{L}$ of $\mathrm{Cu}$ was significantly larger in comparison to control larvae (Johnson et al., 2007). A concomitant decrease of zebrafish length was also observed and the authors concluded that $\mathrm{Cu}$ induced a reduction of yolk utilisation and embryonic rate of development impairment. However, in our study, no diminution of larvae size was observed after $\mathrm{Cu}$ exposure.

Another aspect of heavy metal toxicity that was highlighted during the medaka embryo exposure to $\mathrm{Cd}$ and $\mathrm{Cu}$ was the genotoxic potency of these compounds. Actually, DNA damage was significantly increased in $2 \mathrm{dph}-$ larvae following $\mathrm{Cu}$ and $\mathrm{Cd}$ exposure from the lowest concentration $(1.9 \mu \mathrm{g} / \mathrm{g} \mathrm{Cd}$ and $8.5 \mu \mathrm{g} / \mathrm{g} \mathrm{Cu})$. DNA damage assessed with the comet assay has already been reported in fish cells following $\mathrm{Cu}$ and $\mathrm{Cd}$ during in vivo or in vitro exposures (Risso-de Faverney et al., 2001; Bopp et al., 2008; Morin et al., 2011). It has been

430 hypothesised and partially demonstrated that both heavy metals indirectly generate DNA strand breaks via 431 reactive oxygen species production which could led to cell death and/or apoptosis (Risso-de Faverney et al., 
study seems to confirm this conclusion. However, the origin of such heavily damaged cells is still unclear.

434 Previous works have demonstrated that apoptotic cells did not systematically result in 'hedgehog cells' after 435 comet assay performing (Meintieres et al., 2003). Moreover, it has been reported that these comets, characterised 436 with a small or inexistent head with a highly diffused tail physically separate from the head, could be the result of apoptosis or necrosis but also of high radiation doses or potent mutagen exposures (Burlinson et al., 2007;

438 Kumaravel et al., 2009).

439 Overall observed effects of $\mathrm{Cd}$ and $\mathrm{Cu}$ were very comparable which seems to indicate similar mode of actions, probably based on oxidative stress generation and/or ionoregulation alteration as mentioned above. It had already been reported that equivalent concentrations of $\mathrm{Cu}$ and $\mathrm{Cd}$ caused similar teratogenic impairments in common carp larvae (Lugowska and Witeska, 2004; Lugowska, 2007). The results of the present study are used to establish the LOEC (Lowest Observed Effect Concentration) values for sedimentary compartment as regards the two tested heavy metals using the most sensitive endpoints. Indeed, both percentages of abnormal larvae and tail DNA were significantly increased following the medaka embryo exposure to even the weakest tested concentration of $\mathrm{Cd}$ and $\mathrm{Cu}$, resulting in LOEC values of $1.9 \mu \mathrm{g} / \mathrm{g}(8 \mu \mathrm{g} / \mathrm{L})$ and $8.5 \mu \mathrm{g} / \mathrm{g}(29 \mu \mathrm{g} / \mathrm{L})$ respectively. The values take into account the overall metal content of sediment and indicate a higher toxicity of $\mathrm{Cd}$ compared to that of $\mathrm{Cu}$. Present LOEC values are generally much lower than those reported in the literature, which varied from $0.5 \mu \mathrm{g} / \mathrm{g}$ to $861 \mu \mathrm{g} / \mathrm{g}$ for $\mathrm{Cd}$ (Table 6) and from $17.2 \mu \mathrm{g} / \mathrm{g}$ to more than $820 \mu \mathrm{g} / \mathrm{g}$ for Cu (Table 7). In fact, most of the LOEC were obtained in invertebrates. It can be hypothesised that fish ELS are much more sensitive to metals such as $\mathrm{Cu}$ and $\mathrm{Cd}$. This implies that $\mathrm{Cd}$ and $\mathrm{Cu}$ accumulated in natural sediments may represent a threat for wild fish embryos developing in direct contact to sediments. Indeed, most of the sediments along the Lot-Garonne-Gironde fluvial system present $\mathrm{Cd}$ and/or $\mathrm{Cu}$ contents superior to the LOEC determined in the present study (Table 1). However it should be kept in mind that metal bioavailability likely differs between 'naturally' and artificially contaminated sediments in particular for freshly spiked sediments. In the present study, embryo exposure was performed within 4 to 5 hours following sediment spiking. This probably results in a maximisation of $\mathrm{Cd}$ and $\mathrm{Cu}$ availability and thus to an overestimation of $\mathrm{Cd}$ and $\mathrm{Cu}$ toxic potencies. However, since sediment spiking was performed by simply adding metal-contaminated water to sediment under agitation, this may mimic an accidental and recent release of $\mathrm{Cu}$ or $\mathrm{Cd}$ in aquatic environment (Burton, 1991). Sediment ageing could be performed to better mimic

461 Several sublethal endpoints were significantly induced following $\mathrm{Cd}$ or $\mathrm{Cu}$ exposures and the most sensitive 462 were the percentages of deformed larvae and tail DNA measurement. This kind of sensitive, integrative, low-cost and easy handling endpoints could be really useful in future normalised bioassays to assess the toxicity of 464 sediments.

465 Finally, the present study demonstrated a successful application of MELA to the evaluation of the toxicity of metals accumulated in sediments. As proposed by these authors, a standardisation of the spiking matrix, using an artificial sediment and ageing process, could improve MELA's sensitivity and applicability. Moreover, the MELA could also be enriched by a mechanistic approach using molecular tools for instance, gene expression monitoring, enzymatic activity measurements and/or proteomics analysis performed on embryos and larvae. 


\section{Conclusion}

472 Observations on control embryos demonstrate that the sediment-contact exposure protocol performed in this

473 study provides acceptable conditions for medaka embryo development. Results obtained in contaminated groups showed obvious sublethal effects of both $\mathrm{Cu}$ and $\mathrm{Cd}$ on medaka development. Developmental defects mainly included spinal deformities, yolk-sac malabsorption and cardio-vascular injuries. Moreover, genotoxic effects were induced by both metals in 2-day old medakas. Consequently, the percentage of deformed larvae and tail DNA measurements appeared as relevant markers in sediment toxicity assessment. This study demonstrates the applicability of MELA to the evaluation of sediment hazardous potency at environmental concentrations of metals. Moreover, it confirms the importance of performing both chemical analyses and pertinent toxicity tests to evaluate hazards of pollutants accumulated in sediments since low concentrations of heavy metals could result in non-negligible deleterious effects on early developmental stages of various fish species.

\section{Acknowledgements}

This study was supported by the Aquitaine region, the Seine-Aval program and University of Bordeaux 1 .

\section{References}

Audry, S., Grosbois, C., Bril, H., Schafer, J., Kierczak, J., Blanc, G., 2010. Post-depositional redistribution of trace metals in reservoir sediments of a mining/smelting-impacted watershed (the Lot River, SW France). Appl. Geochem. 25, 778-794.

Audry, S., Schafer, J., Blanc, G., Jouanneau, J. M., 2004. Fifty-year sedimentary record of heavy metal pollution $(\mathrm{Cd}, \mathrm{Zn}, \mathrm{Cu}, \mathrm{Pb})$ in the Lot River reservoirs (France). Environ. Pollut. 132, 413-426.

Benaduce, A. P. S., Kochhann, D., Flores, E. M. M., Dressler, V. L., Baldisserotto, B., 2008. Toxicity of cadmium for silver catfish Rhamdia quelen (Heptapteridae) embryos and larvae at different alkalinities. Arch. Environ. Contam. Toxicol. 54, 274-282.

Blanc, G., Lapaquellerie, Y., Maillet, N., Anschutz, P., 1999. A cadmium budget for the Lot-Garonne fluvial system (France). Hydrobiologia. 410, 331-341.

Bopp, S. K., Abicht, H. K., Knauer, K., 2008. Copper-induced oxidative stress in rainbow trout gill cells. Aquat. Toxicol. 86, 197-204.

Burlinson, B., Tice, R. R., Speit, G., Agurell, E., Brendler-Schwaab, S. Y., Collins, A. R., Escobar, P., Honma, M., Kumaravel, T. S., Nakajima, M., Sasaki, Y. F., Thybaud, V., Uno, Y., Vasquez, M., Hartmann, A., 2007. Fourth International Workgroup on Genotoxicity Testing: Results of the in vivo Comet assay workgroup. Mutat. Res.-Genet. Toxicol. Environ. Mutag. 627, 31-35.

Burton, G. A., Jr, 1991. Assessing the toxicity of freshwater sediments. Environ. Toxicol. Chem. 10, 1585-1627.

Cao, L., Huang, W., Shan, X., Xiao, Z., Wang, Q., Dou, S., 2009. Cadmium toxicity to embryonic-larval development and survival in red sea bream Pagrus major. Ecotoxicol. Environ. Saf. 72, 1966-1974.

Carlson, E. A., Li, Y., Zelikoff, J. T., 2002. Exposure of Japanese medaka (Oryzias latipes) to benzo[a]pyrene suppresses immune function and host resistance against bacterial challenge. Aquat. Toxicol. 56, 289301.

Chapman, P. M., Wang, F. Y., Janssen, C., Persoone, G., Allen, H. E., 1998. Ecotoxicology of metals in aquatic sediments: binding and release, bioavailability, risk assessment, and remediation. Can. J. Fish. Aquat. Sci. 55, 2221-2243. 
Cheng, S. H., Chan, P. K., Wu, R. S. S., 2001. The use of microangiography in detecting aberrant vasculature in zebrafish embryos exposed to cadmium. Aquat. Toxicol. 52, 61-71.

Cheng, S. H., Wai, A. W. K., So, C. H., Wu, R. S. S., 2000. Cellular and molecular basis of cadmium-induced deformities in zebrafish embryos. Environ. Toxicol. Chem. 19, 3024-3031.

Chow, E. S. H., Cheng, S. H., 2003. Cadmium affects muscle type development and axon growth in zebrafish embryonic somitogenesis. Toxicol. Sci. 73, 149-159.

Cline, J. D., 1969. Spectrophotometric determination of hydrogen sulfide in natural waters. Limnol. Oceanogr. $14,454-458$.

Dewitt, T. H., Hickey, C. W., Morrisey, D. J., Nipper, M. G., Roper, D. S., Williamson, R. B., Dam, L. V., Williams, E. K., 1999. Do amphipods have the same concentration-response to contaminated sediment in situ as in vitro? Environ. Toxicol. Chem. 18, 1026-1037.

Ditoro, D. M., Mahony, J. D., Hansen, D. J., Scott, K. J., Carlson, A. R., Ankley, G. T., 1992. Acid volatile sulphide predicts the acute toxicity of cadmium and nickel in sediments. Environ. Sci. Technol. 26, 96101.

EC, Directive 2000/60/EC of the European Parliament and of the Council of 23 October 2000 establishing a framework for Community action in the field of water policy. Vol. L327. Official Journal of the European Communities, 2000, pp. 1-72.

EC, Directive 2010/63/EC of the European Parliament and of the Council of 22 September 2010 on the protection of animals used for scientific purposes. Vol. L273, Official Journal of the European Communities, 2010, pp. 33-79.

Etcheber, H., Relexans, J.-C., Beliard, M., Weber, O., Buscail, R., Heussner, S., 1999. Distribution and quality of sedimentary organic matter on the Aquitanian margin (Bay of Biscay). Deep Sea Research Part II: Topical Studies in Oceanography. 46, 2249-2288.

Eyckmans, M., Tudorache, C., Darras, V. M., Blust, R., De Boeck, G., 2010. Hormonal and ion regulatory response in three freshwater fish species following waterborne copper exposure. Comparative Biochemistry and Physiology Part C Toxicology \& Pharmacology. 152, 270-278.

Farwell, A., Nero, V., Croft, M., Bal, P., Dixon, D. G., 2006. Modified Japanese medaka embryo-larval bioassay for rapid determination of developmental abnormalities. Arch. Environ. Contam. Toxicol. 51, 600-607.

Geffard, O., Toxicité potentielle des sédiments marins et esturiens contaminés : évaluation chimique et biologique, biodisponibilité des contaminants sédimentaires. Ecotoxicology, thesis. University Bordeaux 1, Bordeaux, France, 2001, pp. 376.

Glickman, N. S., Yelon, D., 2002. Cardiac development in zebrafish: coordination of form and function. Semin. Cell Dev. Biol. 13, 507-513.

Gonzalez-Doncel, M., de la Pena, E., Barrueco, C., Hinton, D. E., 2003a. Stage sensitivity of medaka (Oryzias latipes) eggs and embryos to permethrin. Aquat. Toxicol. 62, 255-268.

Gonzalez-Doncel, M., Gonzalez, L., Fernandez-Torija, C., Navas, J. M., Tarazona, J. V., 2008. Toxic effects of an oil spill on fish early life stages may not be exclusively associated to PAHs: Studies with Prestige oil and medaka (Oryzias latipes). Aquat. Toxicol. 87, 280-288.

Gonzalez-Doncel, M., Larrea, M., Sanchez-Fortun, S., Hinton, D. E., 2003b. Influence of water hardening of the chorion on cadmium accumulation in medaka (Oryzias latipes) eggs. Chemosphere. 52, 75-83.

Gonzalez-Doncel, M., Okihiro, M. S., Villalobos, S. A., Hinton, D. E., Tarazona, J. V., 2005. A quick reference guide to the normal development of Oryzias latipes (Teleostei, Adrianichthyidae). J. Appl. Ichthyol. 21, $39-52$.

Grousset, F. E., Jouanneau, J. M., Castaing, P., Lavaux, G., Latouche, C., 1999. A 70 year record of contamination from industrial activity along the Garonne River and its tributaries (SW France). Estuar. Coast. Shelf Sci. 48, 401-414.

Hallare, A. V., Kosmehl, T., Schulze, T., Hollert, H., Kohler, H. R., Triebskorn, R., 2005a. Assessing contamination levels of Laguna Lake sediments (Philippines) using a contact assay with zebrafish (Danio rerio) embryos. Sci. Total Environ. 347, 254-271. 
Hallare, A. V., Schirling, M., Luckenbach, T., Kohler, H. R., Triebskorn, R., 2005b. Combined effects of temperature and cadmium on developmental parameters and biomarker responses in zebrafish (Danio rerio) embryos. J. Therm. Biol. 30, 7-17.

Helmstetter, M.F., Alden R. W. III, 1995. Toxic responses of Japanese medaka (Oryzias latipes) eggs following topical and immersion exposures to pentachlorophenol. Aquat. Toxicol. 32, 15-29.

Hollert, H., Keiter, S., König, N., Rudolf, M., Ulrich, M., Braunbeck, T., 2003. A new sediment contact assay to assess particle-bound pollutants using zebrafish (Danio rerio) embryos. J. Soils Sed. 3, 197-207.

Hove, J. R., Koster, R. W., Forouhar, A. S., Acevedo-Bolton, G., Fraser, S. E., Gharib, M., 2003. Intracardiac fluid forces are an essential epigenetic factor for embryonic cardiogenesis. Nature. 421, 172-177.

Incardona, J. P., Collier, T. K., Scholz, N. L., 2004. Defects in cardiac function precede morphological abnormalities in fish embryos exposed to polycyclic aromatic hydrocarbons. Toxicol. Appl. Pharmacol. 196, 191-205.

Iwamatsu, T., 2004. Stages of normal development in the medaka Oryzias latipes. Mechanisms of Development. 121, 605-618.

Jezierska, B., Lugowska, K., Witeska, M., 2009. The effects of heavy metals on embryonic development of fish (a review). Fish Physiol. Biochem. 35, 625-640.

Jezierska, B., Lugowska, K., Witeska, M., Sarnowski, P., 2000. Malformations of newly hatched common carp larvae. Electronic journal of polish agricultural universities. 3.

Johnson, A., Carew, E., Sloman, K. A., 2007. The effects of copper on the morphological and functional development of zebrafish embryos. Aquat. Toxicol. 84, 431-438.

King, C. K., Gale, S. A., Stauber, J. L., 2006. Acute toxicity and bioaccumulation of aqueous and sedimentbound metals in the estuarine amphipod Melita plumulosa. Environ. Toxicol. 21, 489-504.

Kosmehl, T., Hallare, A. V., Braunbeck, T., Hollert, H., 2008. DNA damage induced by genotoxicants in zebrafish (Danio rerio) embryos after contact exposure to freeze-dried sediment and sediment extracts from Laguna Lake (The Philippines) as measured by the comet assay. Mutat. Res.-Genet. Toxicol. Environ. Mutag. 650, 1-14.

Kosmehl, T., Hallare, A. V., Reifferscheid, G., Manz, W., Braunbeck, T., Hollert, H., 2006. A novel contact assay for testing genotoxicity of chemicals and whole sediments in zebrafish embryos. Environ. Toxicol. Chem. 25, 2097-2106.

Kumaravel, T. S., Vilhar, B., Faux, S. P., Jha, A. N., 2009. Comet Assay measurements: a perspective. Cell Biol. Toxicol. 25, 53-64.

Li, D., Lu, C. L., Wang, J., Hu, W., Cao, Z. F., Sun, D. G., Xia, H. F., Ma, X., 2009. Developmental mechanisms of arsenite toxicity in zebrafish (Danio rerio) embryos. Aquat. Toxicol. 91, 229-237.

Lizardo-Daudt, H. M., Kennedy, C., 2008. Effects of cadmium chloride on the development of rainbow trout Oncorhynchus mykiss early life stages. J. Fish Biol. 73, 702-718.

Lugowska, K., 2007. The effect of cadmium and cadmium/copper mixture during the embryonic development of common carp larvae. Electronic journal of polish agricultural universities. 10.

Lugowska, K., Witeska, M., 2004. The effect of copper exposure during embryonic development on deformations of newly hatched common carp larvae, and further consequences. Electronic journal of polish agricultural universities. 7.

MacDonald, D. D., Ingersoll, C. G., Berger, T. A., 2000. Development and Evaluation of Consensus-Based Sediment Quality Guidelines for Freshwater Ecosystems. Arch. Environ. Contam. Toxicol. 39, 20-31.

Mages, M., Bandow, N., Kuster, E., Brack, W., von Tumpling, W., 2008. Zinc and cadmium accumulation in single zebrafish (Danio rerio) embryos - A total reflection X-ray fluorescence spectrometry application. Spectrochimica Acta Part B-Atomic Spectroscopy. 63, 1443-1449.

Manzl, C., Enrich, J., Ebner, H., Dallinger, R., Krumschnabel, G., 2004. Copper-induced formation of reactive oxygen species causes cell death and disruption of calcium homeostasis in trout hepatocytes. Toxicology. 196, 57-64. 
Marinkovic, M., Verweij, R. A., Nummerdor, G. A., Jonker, M. J., Kraak, M. H. S., Admiraal, W., 2011. Life cycle responses of the midge Chironomus riparius to compounds with different modes of action. Environmental Science and Technology. 45, 1645-1651.

Meintieres, S., Nesslany, F., Pallardy, M., Marzin, D., 2003. Detection of ghost cells in the standard alkaline comet assay is not a good measure of apoptosis. Environ. Mol. Mutag. 41, 260-269.

Morin, B., Filatreau, J., Vicquelin, L., Barjhoux, I., Guinel, S., Leray-Forget, J., Cachot, J., 2011. Detection of DNA damage in yolk-sac larvae of the Japanese Medaka, Oryzias latipes, by the comet assay. Anal. Bioanal. Chem., 1-8.

Nassef, M., Kim, S. G., Seki, M., Kang, I. J., Nano, T., Shimasaki, Y., Oshima, Y., 2010. In ovo nanoinjection of triclosan, diclofenac and carbamazepine affects embryonic development of medaka fish (Oryzias latipes). Chemosphere. 79, 966-973.

Nebeker, A. V., Onjukka, S. T., Cairns, M. A., Krawczyk, D. F., 1986. Survival of Daphnia magna and Hyalella azteca in cadmium-spiked water and sediment. Environ. Toxicol. Chem. 5, 933-938.

OECD, Section 2: Effects on Biotic systems test No. 210: Fish, Early-Life Stage Toxicity Test. OECD Guidelines for the Testing of Chemicals. Organization for Economic Cooperation and Development, Paris, France, 1992, pp. 1-18.

OECD, Section 2: Effects on Biotic systems test No. 212: Fish, Short-term Toxicity Test on Embryo and Sac-fry Stages. OECD Guidelines for the Testing of Chemicals. Organization for Economic Cooperation and Development, Paris, France, 1998, pp. 1-20.

Olive, P. L., Banath, J. P., 1995. Sizing Highly Fragmented DNA in Individual Apoptotic Cells Using the Comet Assay and a DNA Crosslink Agent. Exp. Cell Res. 221, 19-26.

Oxendine, S. L., Cowden, J., Hinton, D. E., Padilla, S., 2006. Vulnerable windows for developmental ethanol toxicity in the Japanese medaka fish (Oryzias latipes). Aquat. Toxicol. 80, 396-404.

Pasteris, A., Vecchi, M., Reynoldson, T. B., Bonomi, G., 2003. Toxicity of copper-spiked sediments to Tubifex tubifex (Oligochaeta, Tubificidae): A comparison of the 28-day reproductive bioassay with a 6-month cohort experiment. Aquat. Toxicol. 65, 253-265.

Risso-de Faverney, C., Devaux, A., Lafaurie, M., Girard, J. P., Bailly, B., Rahmani, R., 2001. Cadmium induces apoptosis and genotoxicity in rainbow trout hepatocytes through generation of reactive oxygene species. Aquat. Toxicol. 53, 65-76.

Roman, Y. E., De Schamphelaere, K. A. C., Nguyen, L. T. H., Janssen, C. R., 2007. Chronic toxicity of copper to five benthic invertebrates in laboratory-formulated sediment: Sensitivity comparison and preliminary risk assessment. Sci. Total Environ. 387, 128-140.

Sandrini, J. Z., Bianchini, A., Trindade, G. S., Nery, L. E. M., Marins, L. F. F., 2009. Reactive oxygen species generation and expression of DNA repair-related genes after copper exposure in zebrafish (Danio rerio) ZFL cells. Aquat. Toxicol. 95, 285-291.

Shinn, C., Dauba, F., Grenouillet, G., Guenard, G., Lek, S., 2009. Temporal variation of heavy metal contamination in fish of the river lot in southern France. Ecotoxicol. Environ. Saf. 72, 1957-1965.

Sidi, S., Rosa, F. M., 2004. Mechanotransduction of hemodynamic forces regulates organogenesis. M SMedecine Sciences. 20, 557-561.

Strickland, J. D. H., Parsons, T. R., 1972. A practical handbook of seawater analysis. Canada Bulletin, Ottawa.

Vicquelin, L., Leray-Forget, J., Peluhet, L., LeMenach, K., Deflandre, B., Anschutz, P., Etcheber, H., Morin, B., Budzinski, H., Cachot, J., 2011. A new spiked sediment assay using embryos of the Japanese medaka specifically designed for a reliable toxicity assessment of hydrophobic chemicals. Aquat. Toxicol. 105, 235-245.

Wittbrodt, J., Shima, A., Schartl, M., 2002. Medaka - A model organism from the Far East. Nature Reviews Genetics. 3, 53-64.

Wong, C. K. C., Wong, M. H., 2000. Morphological and biochemical changes in the gills of Tilapia (Oreochromis mossambicus) to ambient cadmium exposure. Aquat. Toxicol. 48, 517-527. 


\section{Figure captions}

662 Fig. 1. Embryonic (a) and larval (b) viabilities following medaka embryos exposure to $\mathrm{Cd}$ or $\mathrm{Cu}$-spiked

663 sediments. Values represent the mean response $( \pm \mathrm{SD})$ from three replicates. No significant difference was

664 observed between treatments for both heavy metals.

665 Fig. 2. Hatching success (a) and time to hatch (b) following medaka embryos exposure to $\mathrm{Cd}$ or $\mathrm{Cu}$-spiked 666 sediments. Values represent the mean response $( \pm \mathrm{SD})$ from three replicates. No significant difference was 667 observed between treatments for both heavy metals.

668 Fig. 3. Cardiac activity measured in 6 dpf- (a) and 7 dpf-embryos (b) following Cd- or Cu-spiked sediment 669 exposures. Values represent the mean response $( \pm \mathrm{SD})$ from three replicates. For each condition, means with 670 different letters are significantly different $(\mathrm{p}<0.05)$ according to the results of one-way ANOVA followed by 671 Tukey's test.

672 Fig. 4. Total body length (a), head length (b) and head/length ratio (c) of medaka larvae at hatching following $673 \mathrm{Cd}$ - or $\mathrm{Cu}$-spiked sediment exposures. Values represent the mean response $( \pm \mathrm{SD})$ from three replicates. For each 674 experiment, means with different letters are significantly different $(\mathrm{p}<0.05)$ according to the results of one-way 675 ANOVA followed by Tukey's test.

676 Fig. 5. Impact of $\mathrm{Cd}$ and $\mathrm{Cu}$ treatments on DNA integrity of medaka larvae assessed with the comet assay. 677 Percentage of tail DNA (a) was recorded as an indicator of global genotoxic potency of chemicals and the 678 percentage of 'hedgehog' cells (b) was determined to illustrate the presence of necrotic or apoptotic cells. Values 679 represent the mean response $( \pm \mathrm{SD})$ from three replicates. For each experiment, means with different letters are 680 significantly different $(\mathrm{p}<0.05)$ according to the results of one-way ANOVA followed by Tukey’s test. 

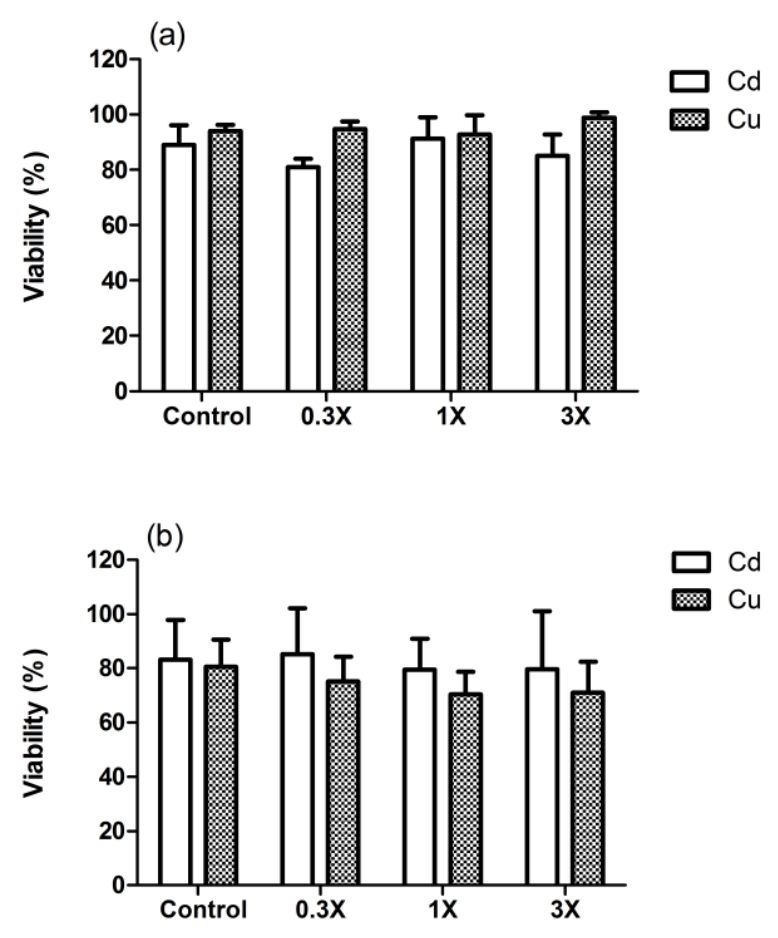

Figures 1a (embryonic viability) and 1b (larval viability) 

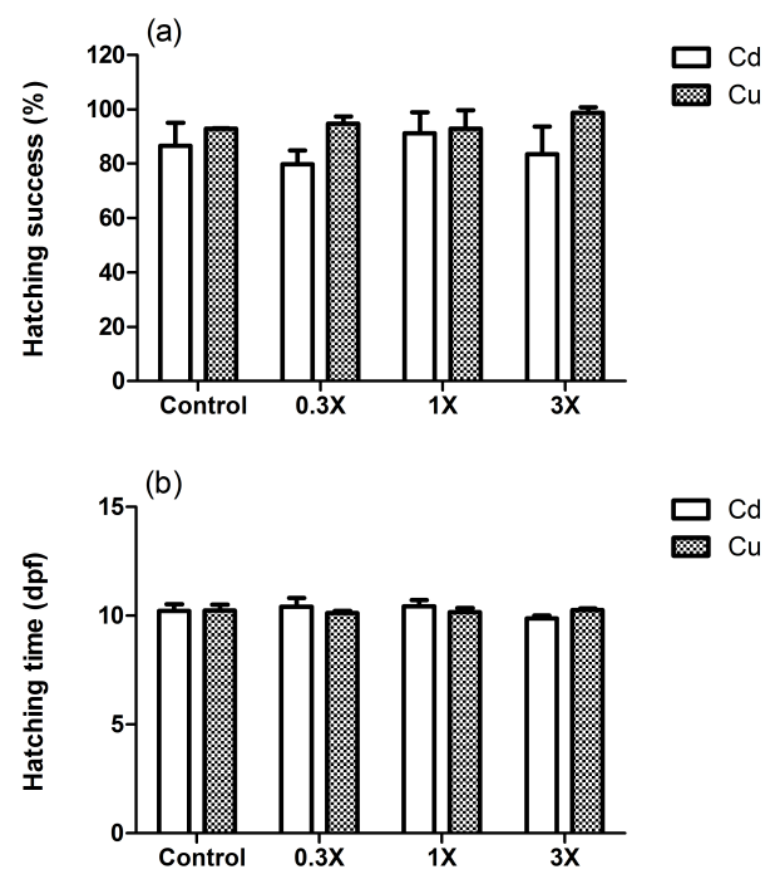

Figures $2 a$ (Hatching success) and $2 b$ (hatching time) 

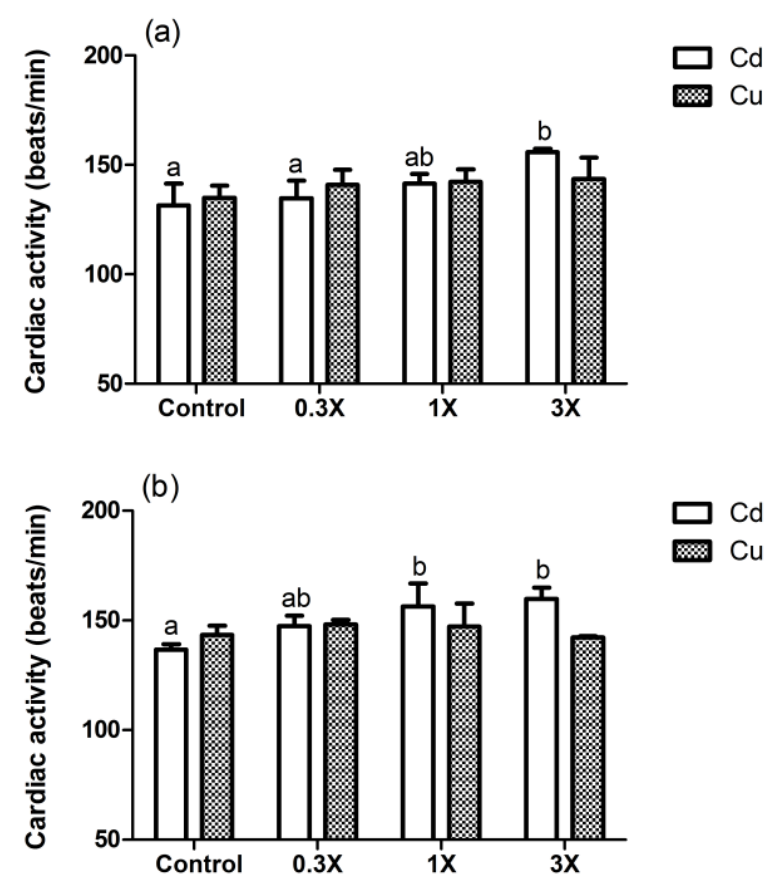

Figures 3a (cardiac activity on 6dpf-embryos) and 3b (cardiac activity on 7dpf-embryos) 

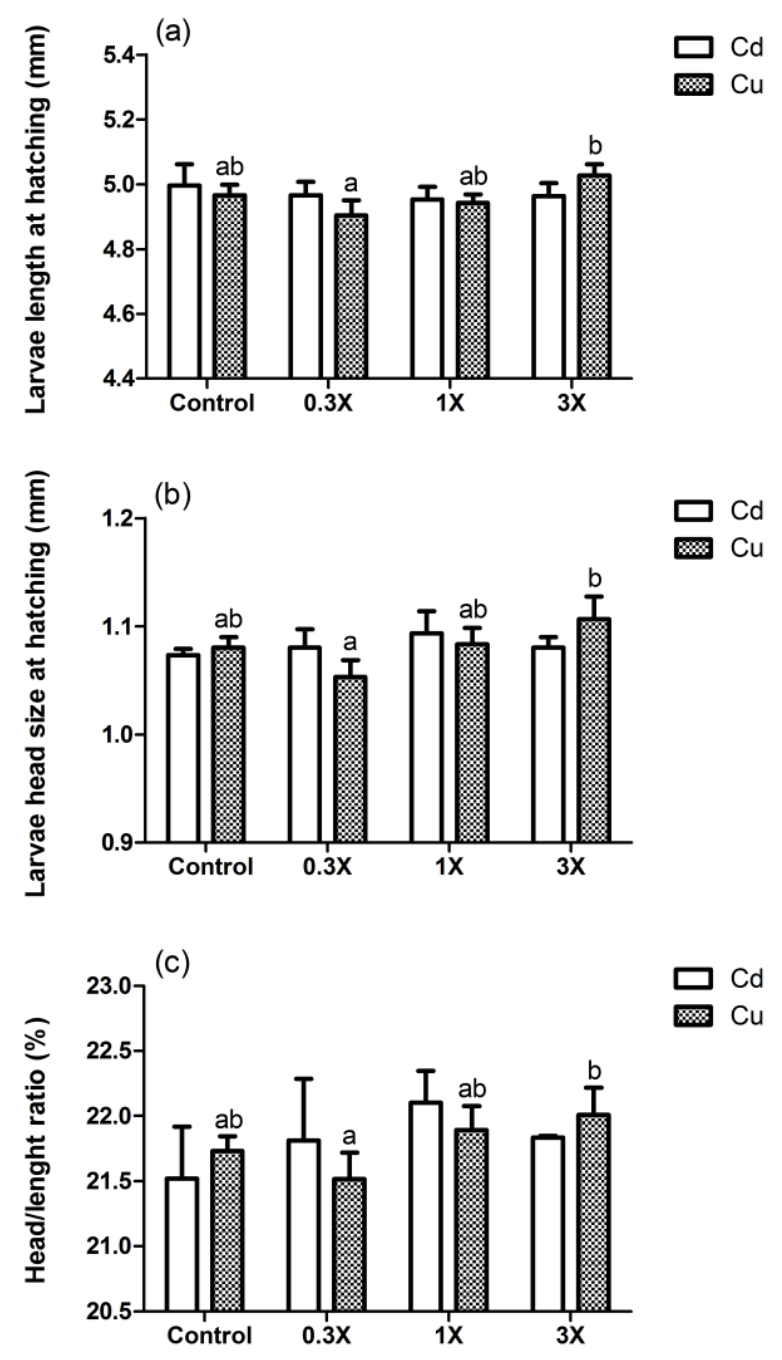

Figures 4a (total body length), 4b (head size) and 4c (ratio head/length) 

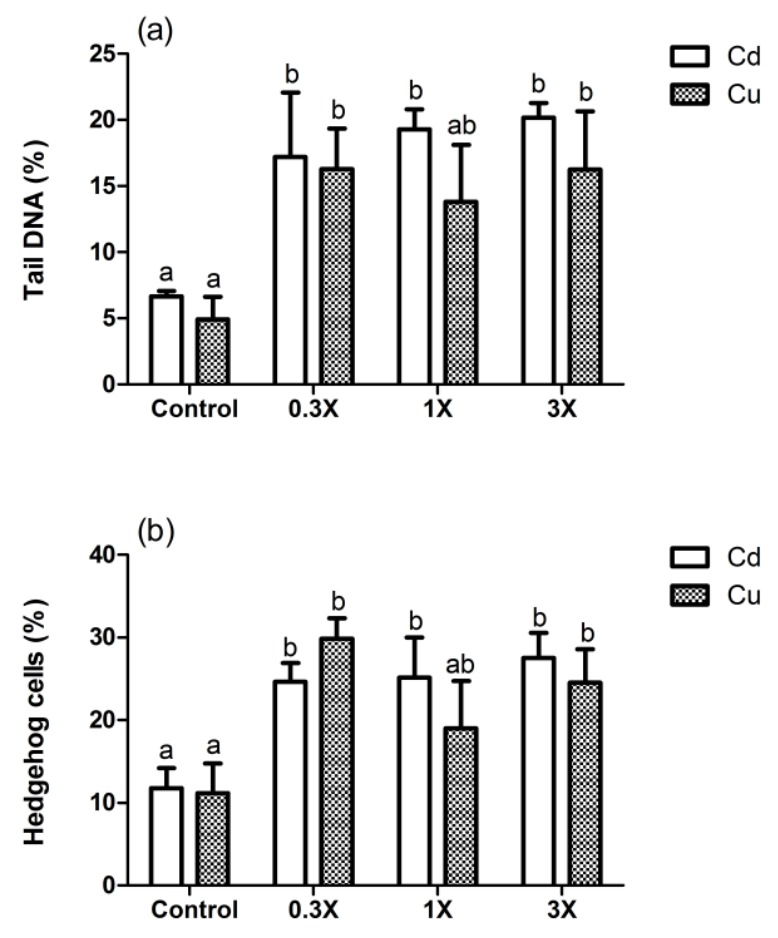

Figures 5a (Tai DNA) and 5b (Hedghog cells) 
Table 1. Reported $\mathrm{Cd}$ and $\mathrm{Cu}$ concentrations in sediments along the Lot-Garonne-Gironde continuum

\begin{tabular}{|c|c|c|c|c|}
\hline Studied area & Sampling site & $\begin{array}{c}\text { Cadmium } \\
(\mu g / g \text { d.w. })\end{array}$ & $\begin{array}{c}\text { Copper } \\
(\mu g / g \text { d.w. })\end{array}$ & Reference \\
\hline \multirow[t]{2}{*}{ Gironde } & Le Verdon & 0.43 & - & (Blanc et al., 1999) \\
\hline & Cheyzin & 0.67 & 33 & (Geffard, 2001) \\
\hline \multirow[t]{6}{*}{ Garonne river } & Bordeaux & 0.7 & 29.5 & (Grousset et al., 1999) \\
\hline & La Réole & 2.6 & - & (Blanc et al., 1999) \\
\hline & Tonneins & 0.93 & 9.6 & (Grousset et al., 1999) \\
\hline & Saint Léger & 0.44 & 17.1 & (Grousset et al., 1999) \\
\hline & Port Pascau & 1.44 & - & (Blanc et al., 1999) \\
\hline & Thouars & 0.41 & 10.3 & (Grousset et al., 1999) \\
\hline \multirow[t]{9}{*}{ Lot river } & Annual mean Temple/Luzech/Carjac 2006 & 14.8 & 24.4 & (Shinn et al., 2009) \\
\hline & Annual mean Temple/Luzech/Carjac 1987 & 41.7 & 31.7 & (Shinn et al., 2009) \\
\hline & Temple & 20.4 & 30.7 & (Audry et al., 2004) \\
\hline & Saint Radegonde & 17 & 22.8 & (Grousset et al., 1999) \\
\hline & Carjac & 125 & 97.7 & (Audry et al., 2004) \\
\hline & Bouillac & 26.4 & - & (Blanc et al., 1999) \\
\hline & Riou & 16.1 & 25.4 & (Grousset et al., 1999) \\
\hline & Decazeville/Riou-Mort & 460 & - & (Blanc et al., 1999) \\
\hline & Marcenac & 0.17 & 7.18 & This study \\
\hline
\end{tabular}


Table 2. Physico-chemical characteristics of the reference sediment (Marcenac, Lot river, France)

\begin{tabular}{ccccccc}
\hline $\mathrm{POC}(\%)^{*}$ & $\mathrm{NH}_{4}{ }^{*}(\mu \mathrm{M})$ & $\mathrm{H}_{2} \mathrm{~S}^{*}(\mu \mathrm{M})$ & $\mathrm{D}(\mathrm{v}, 0.10)^{*} \mu \mathrm{m}$ & $\mathrm{D}(\mathrm{v}, 0.50)^{*} \mu \mathrm{m}$ & $\mathrm{D}(\mathrm{v}, 0.90)^{*} \mu \mathrm{m}$ & $\leq 65 \mu \mathrm{m}(\%)$ \\
\hline 0.11 & 62.3 & 16.8 & 14.75 & 111.49 & 224.74 & 25.82 \\
\hline
\end{tabular}

*POC: particulate organic carbon; $\mathrm{NH}_{4}{ }^{+}$: dissolved ammonia; $\mathrm{H}_{2} \mathrm{~S}$ : dissolved sulfur; $\mathrm{D}(\mathrm{v}, \mathrm{x}): 10,50$ and 90 respective quantiles 
Table 3. Heavy metal concentrations in spiked- and reference sediment at T0 and T10. T10 data are mentioned as mean $\pm \operatorname{SD}(\mathrm{n}=3)$

\begin{tabular}{ccccc}
\hline & \multicolumn{2}{c}{ Cd concentration $(\mu \mathrm{g} / \mathrm{g}$ d.w. $)$} & \multicolumn{2}{c}{ Cu concentration $(\mu \mathrm{g} / \mathrm{g}$ d.w. $)$} \\
& $\mathrm{T} 0$ & $\mathrm{~T} 10$ & $\mathrm{~T} 0$ & $\mathrm{~T} 10$ \\
\hline Cd-spiked sediment & & & & \\
Control & 0.18 & $0.15 \pm 0.00^{\mathrm{a}}$ & 8.05 & $7.35 \pm 0.14$ \\
Cd-0.3X & 1.91 & $1.83 \pm 0.02^{\mathrm{b}}$ & 7.62 & $7.45 \pm 0.11$ \\
Cd-1X & 6.67 & $5.82 \pm 1.69^{\mathrm{c}}$ & 7.36 & $7.43 \pm 0.19$ \\
Cd-3X & 19.80 & $17.13 \pm 1.35^{\mathrm{d}}$ & 7.10 & $8.09 \pm 0.52$ \\
Cu-spiked sediment & & & & \\
Control & 0.25 & - & 6.95 & $7.13 \pm 0.08^{\mathrm{a}}$ \\
Cu-0.3X & 0.19 & - & 8.49 & $8.94 \pm 0.51^{\mathrm{b}}$ \\
Cu-1X & 0.14 & - & 12.70 & $13.03 \pm 0.13^{\mathrm{c}}$ \\
$\mathrm{Cu}-3 \mathrm{X}$ & 0.21 & - & 23.11 & $28.43 \pm 0.64^{\mathrm{d}}$ \\
\hline Other heavy metals contents & in reference sediment $(\mu \mathrm{gg} / \mathrm{g}$ d.w. $)$ & \\
& $\mathrm{Co}$ & $\mathrm{Mn}$ & $\mathrm{Ni}$ & $\mathrm{Zn}$ \\
& 5.6 & 261 & 10 & 35 \\
& $\mathrm{Cr}$ & $\mathrm{As}$ & $\mathrm{Ag}$ & $\mathrm{Pb}$ \\
& 10 & 17.5 & 0.04 & 12.5 \\
\hline
\end{tabular}


Table 4. Concentrations of heavy metal in overlapping ERS buffer from $\mathrm{Cu}$ - and Cd-spiked and control sediment 1 day (T1) and 9 days (T9) after contamination

\begin{tabular}{ccccc}
\hline & \multicolumn{2}{c}{ Cd concentration $(\mu \mathrm{g} / \mathrm{L})$} & \multicolumn{2}{c}{ Cu concentration $(\mu \mathrm{g} / \mathrm{L})$} \\
& $\mathrm{T} 1$ & $\mathrm{~T} 9$ & $\mathrm{~T} 1$ & $\mathrm{~T} 9$ \\
\hline Cadmium exposure & & & & \\
Control buffer & $<1$ & - & & \\
Control sediment & $<1$ & $<1$ & & \\
Cd-0.3X & 8.0 & 11.0 & & \\
Cd-1X & 43.0 & 50.0 & & \\
Cd-3X & 266.0 & 212.0 & & - \\
Copper exposure & & & & 8.7 \\
Control buffer & & & 14.2 & 16.0 \\
Control sediment & & & 29.0 & 28.0 \\
Cu-0.3X & & & 55.0 & 44.0 \\
Cu-1X & & & 60.0 & \\
Cu-3X & & & & \\
\hline
\end{tabular}


Table 5. Developmental deformities observed on larvae at hatching following $\mathrm{Cd}$ or $\mathrm{Cu}$ exposures. Results are expressed in percentage of impaired larvae among overall hatched individuals. Data are mentioned as mean \pm SD $(\mathrm{N}=3)^{*}$

\begin{tabular}{|c|c|c|c|c|c|c|c|}
\hline & $\begin{array}{l}\text { Deformed } \\
\text { larvae }\end{array}$ & Oedematas & $\begin{array}{c}\text { Spinal } \\
\text { deformities }\end{array}$ & $\begin{array}{l}\text { Craniofacial } \\
\text { malformations }\end{array}$ & $\begin{array}{c}\text { Eye } \\
\text { abnormalities }\end{array}$ & $\begin{array}{c}\text { Cardio- } \\
\text { vascular } \\
\text { anomalies }\end{array}$ & $\begin{array}{c}\text { Yolk-sac } \\
\text { deformities }\end{array}$ \\
\hline \multicolumn{8}{|c|}{ Cadmium exposure } \\
\hline Control & $20.33 \pm 4.51^{\mathrm{a}}$ & $4.19 \pm 0.73$ & $6.24 \pm 5.57^{\mathrm{a}}$ & $2.52 \pm 2.20$ & $0.00 \pm 0.00$ & $10.90 \pm 1.01^{\mathrm{a}}$ & $14.10 \pm 6.00$ \\
\hline Cd-0.3X & $72.12 \pm 19.42^{b}$ & $11.36 \pm 3.18$ & $56.21 \pm 23.40^{\mathrm{b}}$ & $1.67 \pm 2.89$ & $1.67 \pm 2.89$ & $25.61 \pm 5.93^{\mathrm{b}}$ & $19.39 \pm 1.05$ \\
\hline Cd-1X & $62.23 \pm 6.34^{\mathrm{b}}$ & $7.07 \pm 3.54$ & $40.74 \pm 8.49^{\mathrm{ab}}$ & $0.00 \pm 0.00$ & $0.00 \pm 0.00$ & $22.11 \pm 3.87^{\mathrm{ab}}$ & $18.41 \pm 7.41$ \\
\hline Cd-3X & $67.97 \pm 18.38^{\mathrm{b}}$ & $7.89 \pm 3.16$ & $58.60 \pm 22.96^{\mathrm{b}}$ & $1.28 \pm 2.22$ & $0.00 \pm 0.00$ & $24.35 \pm 6.05^{\mathrm{b}}$ & $8.69 \pm 3.42$ \\
\hline \multicolumn{8}{|c|}{ Copper exposure } \\
\hline Control & $16.54 \pm 5.21^{\mathrm{a}}$ & $2.47 \pm 4.28$ & $7.55 \pm 6.54^{\mathrm{a}}$ & $3.70 \pm 6.42$ & $2.47 \pm 4.28$ & $9.03 \pm 2.57^{\mathrm{a}}$ & $8.84 \pm 5.50^{\mathrm{a}}$ \\
\hline $\mathrm{Cu}-0.3 \mathrm{X}$ & $51.24 \pm 16.18^{\mathrm{b}}$ & $2.85 \pm 2.48$ & $32.42 \pm 11.30^{\mathrm{ab}}$ & $0.00 \pm 0.00$ & $0.00 \pm 0.00$ & $11.47 \pm 6.67^{\mathrm{a}}$ & $13.63 \pm 3.99^{\mathrm{ab}}$ \\
\hline $\mathrm{Cu}-1 \mathrm{X}$ & $47.61 \pm 2.61^{\mathrm{b}}$ & $5.44 \pm 4.72$ & $18.56 \pm 12.82^{\mathrm{ab}}$ & $1.33 \pm 2.31$ & $0.00 \pm 0.00$ & $29.16 \pm 4.85^{\mathrm{b}}$ & $22.99 \pm 1.87^{\mathrm{b}}$ \\
\hline $\mathrm{Cu}-3 \mathrm{X}$ & $51.92 \pm 6.64^{\mathrm{b}}$ & $2.38 \pm 4.12$ & $35.23 \pm 10.38^{\mathrm{b}}$ & $1.19 \pm 2.06$ & $0.00 \pm 0.00$ & $17.95 \pm 9.30^{\mathrm{ab}}$ & $21.38 \pm 7.17^{\mathrm{ab}}$ \\
\hline
\end{tabular}


Table 6. Toxicity of cadmium to different aquatic organisms using Cd-spiked sediments

\begin{tabular}{|c|c|c|c|c|}
\hline Organism & Endpoint & $\begin{array}{c}\text { Test } \\
\text { duration } \\
\text { (days) }\end{array}$ & $\begin{array}{c}L O E C_{C d} \\
(\mu g / g d . w .)\end{array}$ & References \\
\hline 'Consensus-based TEC**' & - & - & 0.99 & (MacDonald et al., 2000) \\
\hline \multicolumn{5}{|l|}{ Amphipods } \\
\hline Melita plumulosa (adult) & Survival & 10 & $>260$ & (King et al., 2006) \\
\hline Melita plumulosa (juvenile) & Survival & 10 & 820 & (King et al., 2006) \\
\hline Chaetocorophium cf. lucasi & Survival & 10 & 748 (in situ) & (Dewitt et al., 1999) \\
\hline Hyalella azteca & Survival & 4 & $128 *$ & (Nebeker et al., 1986) \\
\hline \multicolumn{5}{|l|}{ Gastropods } \\
\hline Helisoma $s p$ & Survival & 10 & $340 *$ & (Ditoro et al., 1992) \\
\hline Insect larvae & & & & \\
\hline Chironomus riparius & Emergence & 28 & 0.5 & (Marinkovic et al., 2011) \\
\hline
\end{tabular}

*NOEC value $; *$ TEC $=$ Threshold effect concentration 
Table 7. Toxicity of copper to different aquatic organisms using $\mathrm{Cu}$-spiked sediments

\begin{tabular}{|c|c|c|c|c|}
\hline Organism & Endpoint & $\begin{array}{c}\text { Test } \\
\text { duration }\end{array}$ & $\begin{array}{c}L O E C_{C u} \\
(\mu g / g d . w .)\end{array}$ & Reference \\
\hline 'Consensus-based TEC'**' & - & - & 31.6 & (MacDonald et al., 2000) \\
\hline \multicolumn{5}{|l|}{ Amphipods } \\
\hline Hyalella azteca & Survival & 14days & 180 & (Roman et al., 2007) \\
\hline Hyalella azteca & Growth & 28days & 95.4 & (Roman et al., 2007) \\
\hline Gammarus pulex & Survival/growth & 35days & 176 & (Roman et al., 2007) \\
\hline Melita plumulosa (adult) & Survival & 10days & 550 & (King et al., 2006) \\
\hline Melita plumulosa (juvenile) & Survival & 10days & 820 & (King et al., 2006) \\
\hline \multicolumn{5}{|l|}{ Insect larvae } \\
\hline Chironomus riparius & Survival & 14days & 180 & (Roman et al., 2007) \\
\hline Chironomus riparius & Growth & 28days & 188 & (Roman et al., 2007) \\
\hline Chironomus riparius & Emergence & 28days & 89.2 & (Roman et al., 2007) \\
\hline Chironomus riparius & Emergence & 28days & 17.2 & (Marinkovic et al., 2011) \\
\hline \multicolumn{5}{|l|}{ Oligochaetes } \\
\hline Lumbriculus variegatus & Survival & 28days & 140 & (Roman et al., 2007) \\
\hline Lumbriculus variegatus & Biomass & 28days & 103 & (Roman et al., 2007) \\
\hline Lumbriculus variegatus & Reproduction & 28days & 103 & (Roman et al., 2007) \\
\hline Tubifex tubifex & Survival & 28days & 158 & (Roman et al., 2007) \\
\hline Tubifex tubifex & Growth & 28days & 102 & (Roman et al., 2007) \\
\hline Tubifex tubifex & Reproduction & 28days & 102 & (Roman et al., 2007) \\
\hline Tubifex tubifex & Reproduction & 28days & $92-166$ & (Pasteris et al., 2003) \\
\hline
\end{tabular}

$*$ NOEC value $; *$ TEC $=$ Threshold effect concentration 